\title{
Understanding the Integration of Socio-Technical Actors for Sharing and Sustainable Urban Mobility
}

\author{
Carlos Henrique T. Pereira ${ }^{1}$ \\ chtpereira@hotmail.com | (DD0000-0001-7141-5367 \\ Minelle E. Silva ${ }^{1}$ \\ minele.adm@gmail.com | (D)0000-0003-2074-6478
}

\begin{abstract}
In the search for sustainability and urban reconfiguration, this research analyzes a business model used in sustainable urban mobility initiatives that integrates public and private agents (socio-technical actors - ST-actors) in Fortaleza (Brazil). An integrated case study was carried out with two initiatives: VAMO Fortaleza (e-carsharing) and Bicicletar (bike sharing). Interviews were conducted with the protagonist ST-actors, and documents were analyzed focusing on shared urban mobility. We observed that the initiative implementation integrates ST-actors through public-private partnerships. Based on that, a schematic model was designed to illustrate ST-actor integration as a business model that can be replicated in other contexts using sharing economy principles. In the context of the urban mobility reconfiguration focused on sustainability, we explore a case which has been internationally recognised and we present an underexplored theme about sharing economy initiatives that can be practised.
\end{abstract}

\section{KEYWORDS}

Sharing Economy, Business Model, Sociotechnical Actors, Sustainable Urban Mobility, Public-Private Partnership 


\section{INTRODUCTION}

Over the past few years, sustainability has become central to economic and political debates worldwide. This perspective is based on a gradual and incremental long-term transition. It is known that conventional solutions are not enough to solve the current problems, so we seek the composition of economically viable structures that contribute to the basic premises of sustainability, such as the sharing economy (SE). This study focuses on contributing to academics and professionals from public and private initiatives, who are interested in how to operationalize and integrate multiple actors into reconfigurations of urban shared mobility that are economically viable and sustainable. Therefore, in this paper, we study solutions developed in the urban context of Fortaleza (Brazil) and its SE initiatives.

Based on the synergy of economic and social systems, SE emerges as a business model that allows shared access to goods, services, data, talents and other assets, often supported by digital platforms (Belk, 2014a; Botsman \& Rogers, 2010). Thus, SE is a model capable of contributing to a sustainability agenda in different fields such as urban mobility (Albuquerque, Bellini, \& Pereira, 2009; Pereira \& Silva, 2018; 2017). For this end, SE can be seen developing sharing actions of intermodal urban transport systems or acting as a technological niche.

Within urban mobility debates, changes are needed to reduce $\mathrm{CO} 2$ emissions and traffic in cities, for example. This would be possible with a reduction in the circulation of private cars. As found in Transportation Research Board studies, sharing can reduce the circulation of at least five private cars (Rubicon, 2015). This number reaches 13 private cars in research by the University of California Transportation Center. Research has been developed to mean bike sharing, as in Fortaleza (Rechene, Silva, \& Campos, 2018) and other Brazilian cities, or based on carsharing, such as in the cities of Sydney, London and Paris (Akyelken, Banister, \& Givoni, 2018; Terriena et al., 2016).

The literature recognizes that systemic changes in urban mobility are necessary and that such reconfigurations demand the integration of multiple actors, for example, through Public-Private Partnerships (PPP). However, it is not known how these PPP's actors need to be organized to introduce sustainable urban mobility. The first theoretical gap to be studied arises to include how socio-technical actors are organized around initiatives of shared and sustainable urban mobility. In this context, sociotechnical actors are understood as those economic agents who act on technical and social (institutional) fronts favorable to urban reconfiguration. One perspective to observe such integration is through PPPs following a logic of sharing the responsibility for transforming mobility.

In this sense, the government seeks social development and manifests itself in different ways, such as adapting legislation, financial incentives through subsidies or tax exemptions, management of public spaces, and services. The private sector, however, develops technology aiming at conducting economically viable businesses, while local governments and private companies have been looking for models of joint action. Despite this view, there is a theoretical gap in how to overcome challenges such as the coordination of integrated initiatives, in the construction of unique transport systems.

The central issue involves conducting studies that increase the understanding of how successful SE initiatives can be structured, especially in emerging countries (Köhler et al., 2019). Thus, based on these gaps, this research aims to analyze the sharing business model used in sustainable urban mobility initiatives. Therefore, through an exploratory case study of actions with international recognition, we seek to demonstrate how the integration between public and private agents 
BBR

17

708

is structured through the implementation of shared urban mobility initiatives (VAMO and Bicicletar) in operation in the city of Fortaleza (CE), fifth largest capital of Brazil by the number of inhabitants (IBGE, 2016).

The choice is justified, as Fortaleza entered the list of the World Health Organization (WHO), as an example in the adoption of sharing and use of public spaces (Diário do Nordeste, 2019; World Health Organization, 2019). The results show that for shared and sustainable mobility to be implemented, several actors are needed, who need to play specific roles in their activities. It is worth noting that these roles are and must be recognized by the other socio-technical actors involved for the implemented business model to be successful. PPP is not limited to creating links, but to develop the different actors in order to achieve a real urban reconfiguration.

This research contributes: (1) to debate about the organization of actors through a structure that operationalizes and integrates multiple actors in economically viable and sustainable urban reconfigurations in shared mobility (Geels, 2018; Martin, 2016); (2) in the study of PPP that is still lacking in the integration of multiple agents. Thus, this research shows a greater understanding of the potential roles of the agents involved in such reconfigurations (Terrien, Maniak, Chen, \& Shaheen, 2016), for a local solution; and (3) for the objectives of sustainable development (SDGs) 11 (sustainable cities and communities) and 12 (responsible consumption and production), presenting a model of shared mobility in an emerging country. In practice, this study presents an integrative model that can be used by private and public managers for potential replication in other contexts.

\section{LITERATURE REVIEW}

\subsection{SHARING ECONOMY: UNDERSTANDINGS AND CONCEPTS}

Sharing is an act intrinsic to humanity, which gains sharing consumption status with internet access (Belk, 2014b). Based on the idea that sharing suggests alternatives such as market exchanges with collections (sale and rent, for example) and free items (donations), for Belk (2007) sharing would be the action and/or process of distributing what is ours for what others can use. Similarly, it refers to the action and/or process of receiving something from others so that it can be used. Thus, sharing involves different situations, occurs with or without profit, with or without the exchange of property, and includes a set of tangible and intangible resources (Belk, 2014a).

The debate about the real frontier between pure sharing and its derivations causes the emergence of different views that do not corroborate the composition of a unified concept for SE. There are several ambiguities and confusions in the use of the sharing principle (Belk, 2014a), which generate variations in the use of the term (Burnett, 2014; Demailly \& Novel, 2014; Frenken \& Schor, 2017). These variations are identified when it is seen that different authors explore terms with different concepts. However, in general, the definitions involving SE are not contradictory in nature, but distinct in scope and breadth of the elements that compose it (Allen \& Berg, 2014).

SE emerged around 1990 in the United States (Botsman \& Rogers, 2010; Olsen \& Kemp, 2015; Schor \& Fitzmaurice, 2015), contributing to the vision in which sharing and exchange between peers has its roots in American culture (Burnett, 2014). It is believed that the economic crisis of the 2000s created a process of distrust in outdated technological concepts, fostering new technological, economic and social approaches (Botsman \& Rogers, 2010; Heinrichs, 2013; Schor, 2014). In this context, the SE emerges that grows and gains global amplitude in the world economic crisis observed in 2008 (Belk, 2014b; Schor, 2014). 
Amid its growth, agents or peers on the consumption side of SE, called user peers, seek to reevaluate what is, in fact, valuable, considering views about having or simply having access. Despite the intense debate, there is still no united concept of SE (Cockayne, 2016; Demailly \& Novel, 2014; Frenken \& Schor, 2017). The term Sharing Economy is accepted as generic and capable of representing several meanings (Frenken, 2017; Heinrichs, 2013; Sundararajan, 2016).

$\mathrm{SE}$ is considered a new business modality in the light of the traditional economy, as it is characterized by the sharing of assets classified as tangible and intangible, acts in the reduction of intermediaries, and is able to improve direct connections between the different agents (Belk, 2014b; Carfagna et al., 2014). Additionally, Botsman and Rogers (2010) affirm that SE is based on the sharing of idle goods and services, which can occur free of charge or in a remunerated way. For that, it is necessary: the generation of value (monetary and non-monetary) from the exploration of idle assets; the valuation of peers on the supply side, whether companies or not, from an economic and social point of view; benefit peers on the demand side with the ability to obtain products and services more efficiently, being able to generate only access and not necessarily ownership

Botsman and Rogers (2010) corroborate with the SE literature in a broad perspective, which address both supply and demand side (i.e., production and consumption). In addition, we can see social and behavioral fundamentals in the SE capacity to act in scenarios composed by multiple economic agents, such as public and private initiatives. The transactions involved in SE, according to Rustrum et al. (2014), include buying and selling, rent, loan, simple exchange or even the gift-giving exercise. Botsman and Rogers (2010) are more comprehensive about SE transaction and claim that different modalities exist, such as sharing, rent, loan, donation, exchanges and even barter (Pereira \& Silva, 2018; 2017).

Therefore, SE is considered the result of the union of three economic trends: the second-hand economy, the economy of products and services and the economy on demand. Such configurations cover different consumption models of SE, such as P2P consumption, whose role of a mediating company is eliminated, the consumption of underutilized goods, when the concept of circular economy acts in the optimization of resource use and, finally, the consumption without the exchange of ownership, in which access is more important than ownership (Frenken, 2017).

The consultancy Altimeter (Owyang, 2016), as well as Botsman and Rogers (2010), considers that SE results from the combination of three drivers or groups of factors: social, bringing an increase in population density, the search for sustainability and altruistic actions); economic ones due to greater financing flexibility, access being more valuable than ownership, monetization of different types of idle assets and increased investments dedicated to collaborative projects) and technological ones (marked by the growth of social networks, the diffusion of mobility with the use of smart and interconnected devices and the improvement of the payment system through the internet).

In a similar way, there are approaches that define $\mathrm{SE}$ as a system promoted by the connection of economic, social, and environmental factors (Daunorienè, Drakšaité, Snieška, \& Valodkienė, 2015). As indicated by Krupinsk (2015), in SE there are different roles that can be identified for both individuals and companies: providing products or services, fostering the market, or providing digital platforms. Thus, based on the roles, relationships can be observed: those between peers (Peers to Peers - P2P), companies - pairs (Business to Peers - B2P), between companies (Business to Business - B2B) and in the triangulation pairs - companies - peers (peer to business to peer - P2B2P) (Glind, 2015). 
BBR

17

710

The non-uniformity observed in the concepts/definitions, elements, nomenclature, and performance of the economic agents involved in SE, also occurs in their taxonomies. That is, different taxonomies are observed based on different criteria such as the orientation of the digital platforms used - profitable and non-profit or in the market structures planned and already mentioned - P2P or B2P (Schor, 2014). Moreover, there is a classification oriented according to collaborative activities (Botsman \& Rogers, 2010). Considering these arguments and based on the discussion presented by Pereira e Silva (2018), it is understood that there must be a search to advance in studies on sharing economy. Thus, CE is defined as:

A socio-technical business model (which includes economic, social and technical elements), that is capable to promote shared access to goods, services, data and talents, through a hybrid market model, which travels between ownership and donation, of transactions between peers, normally supported by digital platforms.

Following this definition, we have that the socio-technical approach of SE and must consider both the relationships between the actors, as well as the digital technology used to promote the distribution, sharing, reuse, and other forms of the transaction of excess capacity of assets. The use of this definition involves semantic derivations (other concepts) and allows our research to increase the expected results. Figure 1 proposes a scheme of the proposed concept of SE, and accepts its umbrella condition, in which its main elements (systems, drivers and forms of transaction) and its amplitude are exposed.

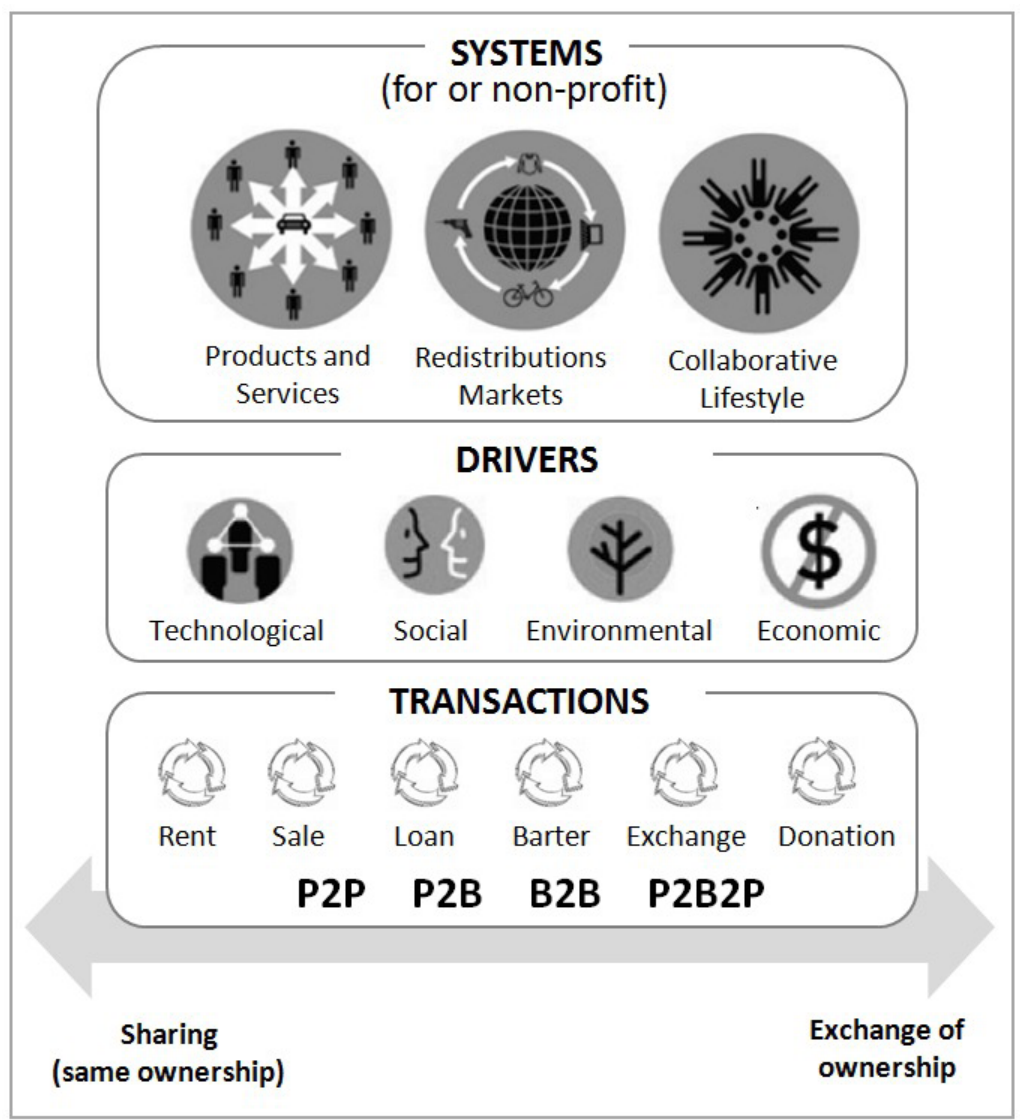

Figure 1. Scheme illustrating the SE elements. Source: Own elaboration (2018). 
Given the multiple contributions that SE offers, it is possible to see it as an alternative towards sustainability. Within this debate, there are many discussions that corroborate the prerogative that SE contributes to sustainability (Heinrichs, 2013; Rubicon, 2015; Schor, 2014). For example, according to Carfagna et al. (2014) and Daunoriene et al. (2015), SE can restore the balance between economic, social, and environmental factors. Additionally, the SE meets the so-called holy trinity (efficiency, consistency and sufficiency) and, for this reason, promotes a more sustainable society (Heinrichs, 2013).

\subsection{Sharing Economy, Sustainability and Urban Mobility}

The role of SE in urban sustainability stands out as one of the subjects of greatest demand in society (Wu \& Zhi, 2016), thus there are still discussions on regulatory, technological, political and other issues that involve sustainability. According to Daunnoriene et al. (2015), SE provides greater stability of physical and biological systems and a reduction in product production. However, the authors have made the point that this SE property depends on specific conditions and may vary depending on the business model. Hence, the SE is credited with greater efficiency in the use of natural resources from the greater use of idle assets (Fremstad, 2015; World Economic Forum, 2013).

Contributions attributed to SE also arise from its role as a generator of jobs, by encouraging the use of digital platforms that generate mass business with low transaction costs and lower information asymmetries, benefiting the supply and demand sides (Fremstad, 2015; Sundararajan, 2016). In this way, SE allows for an increase in the number of economically active agents acting to reduce marginal costs (Rifkin, 2016; World Economic Forum, 2013). Furthermore, the SE allows for a reduction in the production of goods and, consequently, generates a reduction in the consumption of energy and natural resources. Based on these reductions, SE also contributes to the reduction of waste in the environment (Fremstad, 2015).

In this context, studies show that good management of shared goods reduces the production of household waste by about 20\%, and household expenses by $7 \%$ (Demailly \& Novel, 2014). SE is also credited with sustainability benefits in initiatives that encourage the use of shared cars and bikes. Such benefits are seen, for example, in the reduction of carbon emissions - CO2, decrease in the demand for parking lots, reduction in the number of kilometers travelled by vehicles and reduction in the acquisition of vehicles (Luna, Uriona-Maldonado, Silva \& Vaz, 2020; Nijland \& Meerkerk, 2017; Schor, 2014).

Despite these arguments, many numbers about $S E$ are questioned, and the occurrence of side effects is increasingly present in the debates (Heinrichs, 2013; Schor, 2014). Dysfunctions arise in the social, economic, and environmental dimensions, mainly due to the absence of studies that prove the benefits to sustainability (Frenken, 2017). Social problems arise with prejudices and unequal treatment involving racial issues and economic standards (Rubicon, 2015), and the exploitation of work (Schor, 2014). In the environmental dimension, there is a concern regarding the encouragement of hyper consumption (Demailly \& Novel, 2014; Frenken, 2017; Schor, 2014 ) or even the simple expansion of consumption without complying with good practices, by involving what Prahalad and Hart (2000) call the base of the pyramid.

Based on so many scenarios, the benefit or impact caused by SE to the environment will depend, among other factors, on the regulation and institutionalized socio-technical structure. We understand, therefore, how important it is to analyze the structures in designing the models foreseen to explore sharing. Thus, businesses within SE can be explored on different platforms, 
BBR

17

712

such as capitalist, redistributive, or cooperative platforms (Frenken, 2017). Heinrichs (2013) notes that, to connect SE and sustainability, it is possible to establish key points, such as (1) the influence of changing consumption habits and practices on environmental and sustainable awareness and (2) the debate on economic growth and new indicators about the quality of life and wealth associated with SE practices.

Thus, the SE is seen amid the debate on business structures that integrate different economic agents and are in conformity with the principles of sustainability. Structures in SE must consider technological, behavioral and institutional factors, in both production and consumption sides. We believe that SE generates "digital partner" experiences, deals with ongoing technological processes and with the ability to integrate different digital technologies and new structures in different business models and social organizations (Martin, 2016, p. 159). Furthermore, SE can be seen as a contributory instrument, given its ability to operate in different business models, leading the integration of multiple ST-actors in public and private initiatives.

The adherence to the concepts of sharing has brought about social changes and caused positive impacts in several sectors. Therefore, SE has been used as a basis for urban reconfigurations, for example, in the scope of mobility. The mobility sector has emerged as one of the most evolved in recent years ("Economia compartilhada transforma a mobilidade humana," 2018). The shared mobility, whether motor vehicle, bike or other modes, has provided short-term access to modes of transport, linked to the needs of each user (Shaheen \& Chan, 2016). That is, "on-demand" access to shared mobility adds greater flexibility to travelers and presents itself as a more sustainable alternative (Shaheen \& Chan, 2016).

Concerning the mobility discussion, there are gaps and opportunities to be explored, based on the understanding and adequacy of urban transport structures in order to better adapt to the profile of users not yet adhering to SE. Regarding the electric vehicles, their diffusion is still slow, and the general public sees them in a skeptical light. However, studies suggest that people are familiar with this option in the context of urban sharing, that is, using it in a similar way to conventional vehicles. Therefore, the SE supports the adoption of electric mobility, promoting more sustainable transport (Willing, Brandt, \& Neumann, 2016).

\section{METHODOLOGY}

In order to analyze SE initiatives developed through the integration of multiple ST-actors, we employed a qualitative-exploratory approach and uses case study as the research strategy. A single case study is considered when exploring an integrated context, experienced as a unit with defined borders in a single environment. Thus, a case study is understood, according to Yin (2005, p. 32), as "an empirical investigation that investigates a contemporary phenomenon within its real-life context" that appears as a valid means of "understanding complex social phenomena" amid a" wide variety of evidence" (Yin, 2005, p. 27).

Having said that, this research opted for a nested case study composed of the integration of two urban mobility initiatives in the city of Fortaleza (Brazil), configured in two modes based on the premises of SE. It is a case study inserted into a daily dynamic of mobility composed by electric carsharing and bike sharing. The object of analysis refers to the integration of the initiatives called VAMO Fortaleza and Bicicletar. The research subjects are all those stakeholders involved with its implementation and maintenance. 
To gather data, we used a set of sources. However, we prioritized to obtain information directly from the protagonist ST-actors. Therefore, direct contact instruments were used, composed of semi-structured interviews (Chart 1 ) and informal conversations. The interviews were recorded and transcribed, being validated by the interviewees. In parallel, documentary research was carried out, being a document "any support that contains registered information, forming a unit that can be used for consultation, study or proof" (Appolinário, 2009, p. 67). In this research, electronic sites, technical reports, reports, public calls, lectures and legislation were considered.

Chart 1

Summary of interviews

\begin{tabular}{|lcccc|}
\hline ST-Actor & Code & Format & Date & Duration \\
\hline Fortaleza City Hall & ENTPREF1 & Face to Face & $13 / \mathrm{Nov} / 17$ & 54 Minutes \\
Fortaleza City Hall & ENTPREF2 & Face to Face & $13 / \mathrm{Nov} / 17$ & 54 Minutes \\
Serttel & ENTSERT1 & Skype & $13 / \mathrm{Dec} / 17$ & 33 Minutes \\
Unifor & ENTUNIF1 & Face to Face & $30 / \mathrm{Nov} / 17$ & 34 Minutes \\
Enel & ENTENEL1 & Face to Face & $16 / \mathrm{Jan} / 18$ & 17 Minutes \\
Hapvida & ENTHAPV1 & E-mail & $24 / \mathrm{Mar} / 18$ & - \\
Ciclovida Group & ENTCICV1 & E-mail & $05 / \mathrm{Jun} / 18$ & - \\
\hline
\end{tabular}

Source: Own elaboration (2018).

The Chart 1 summarizes the dynamics of the seven interviews conducted, highlighting the ST-actors involved through codenames and other details about the data survey. Concerning ethical issues, we obtained the consent of all participants to carry out the research. It can be seen that face-to-face and remote interviews were carried out, which were intermediated by means of communication software (Skype). In addition, we also used e-mails, consisting of interview scripts for ST-Government and ST-Non-Government actors to collect some data. The selected quotations were translated into English by both scholars.

In regard to data analysis, a content analysis was carried out (Bardin, 2016), to enrich the "reading through the understanding of meanings and the need to unveil relationships that are established beyond the lines, properly said" (Cavalcante, Calixto, \& Macedo, 2014, p. 14). The basis for applying the analysis technique was composed of the selected documentary set, notes, transcriptions and other records originated during the empirical stage. Concerning the research quality criteria, we used two basic concepts: validity and reliability (Godoy, 2005). The first refers more to accuracy while the second to the possibility of replicating the theory. Both meet a kind of "minimum agenda" (Godoy, 2005, p. 85), promoted in this study with the generation of results through triangulation of opinion (validity) and the validation of results by sending them to those involved (reliability).

\section{FINDINGS}

In order to better meet the research objective, this section presents the initiatives studied, followed by an overview of the ST-actors involved in the case and a discussion about the integration model identified. 


\subsection{SHARING ECONOMY INITIATIVES: CASE DETAILS}

Two initiatives were studied (Bicicletar and VAMO) integrated into a nested case study. Both initiatives are related to the Fortaleza 2040 sustainable city project existent. The Bicicletar refers to "a public bicycle system, which aims to offer the city of Fortaleza a sustainable and nonpolluting transport option" (Prefeitura de Fortaleza, 2018). The system is an initiative of the City Hall of Fortaleza, operated by Serttel, and which works with the support of the sponsor Unimed Fortaleza, a cooperative of doctors. According to the city hall representative, Bicicletar is defined as "a public system, with a private operator, a private sponsor, encouraging the use of the bicycle (...)" (ENTPREF2).

The Bicicletar System is composed of "smart stations connected to an operations center via wireless" (Prefeitura de Fortaleza, 2018). The stations are powered by renewable energy because according to the initiative's representative "the energy base is solar, we have one or another connection to the electricity base coming from the Enel network, but as an backup, if [the] solar energy is not enough to use to make the system work." (ENTPREF2). In addition, the stations are strategically distributed in different parts of the city (Prefeitura de Fortaleza, 2018), to facilitate the access by the largest number of people.

This initiative arises with the political support, the growth of cyclo-activism in the city and the creation of the legal instrument called "Plano Diretor Cicloviário Integrado" (PDCI), in 2014. The approval of the PDCI, through the law No. 10,303 of December 23, 2014, created the Cycle Management of Fortaleza, composed by a multidisciplinary team including architects and engineers, with a focus on the implementation of the cycle plan with a horizon of action until 2030. The Bike is legitimized through a public call and opens on the 15th December 2014, initially with 15 stations, but it is expanded to 40 stations on May 15, 2015. In September 2018, the system included 80 stations (Soares, 2018).

In regard to the electric carsharing, VAMO Fortaleza ("Veículos Alternativos para Mobilidade" Alternative Mobility Vehicles, in English), it is "an initiative to promote sustainable urban mobility through a network of shared electric cars, available in the city of Fortaleza" (Prefeitura de Fortaleza, 2017). According to city hall reports, the initiative comes as a response to the excessive use of private cars in Fortaleza, which increased problems such as noise and environmental pollution, added to the opportunities for the development of urban infrastructure. Since there is a macro project to move the city to a sustainable one, it was necessary to rethink a set of actions, which included mobility.

In this context, the City Hall of Fortaleza started a process of breaking paradigms in the municipality by adopting actions aligned with the National Urban Mobility Policy (Law No. 12,587/2012), for example, with the launch, in 2014, of the Immediate Action Plan in Transport and Transit (PAITT), made available during the interview. Thus, inserted in this set of public actions of sustainable urban mobility and the concept of sharing, in September 2016, the first public system of electric carsharing in Brazil, VAMO Fortaleza, was inaugurated, originally composed by 20 vehicles that are $100 \%$ electric, allocated to 12 stations installed in strategic public places. As the City Hall representative mentions, VAMO “(...) came to break the paradigm of use, it is not even the misuse, but the exacerbated use of private transport, right” (ENTPREF1). Ratifying the understanding of broad change in the mobility system.

The use of electric carsharing by users occurs through applications installed on mobile devices (cell phones, tablets, etc.) or through the single ticket. Amidst the characteristics of the initiatives, the premises of the SE already described in the theoretical framework are soon identified, making it possible to characterize the initiatives as systems of products and services, with technological, 
social, environmental and economic drivers, which enable transactions closer to the P2B2P concept, with a model without changing ownership. This discussion brings up the need to understand those involved and the process of structuring these initiatives.

Based on this discussion, it is understood that there is a debate about sharing in the integration of ST-actors. As can be seen in the speech by the city hall representative below, the models begin to stand out for this reason: "The Bicicletar, (...), it showed me what in fact, how does sharing really work here in Fortaleza. The same basic principles adopted by Bicicletar were adopted for VAMO." (ENTPREF1). Therefore, two integrated initiatives are verified and fully aligned with the concept of sharing, introduced in the current transport system and that contribute to sustainable mobility in the urban space.

\subsection{ANALYSIS OF THE INTEGRATION OF MULTIPLE ST-ACTORS}

We identified the first protagonist ST-actors through initials research about the case, developed by reading the websites of the two initiatives (VAMO and Bicicletar) and reports relevant to the city's shared mobility. Then, throughout the documentary study and interviews with the first two ST-actors (Fortaleza City Hall and Serttel), it was possible to define the other actors. This procedure considered the indication and agreement of the respondents themselves, through the crossing and legitimation of the indications (Chart 2).

Chart 2

Model of identification of ST-actors and their main roles.

\begin{tabular}{|c|c|c|c|}
\hline Record & Role & Actor-ST & Source \\
\hline $\begin{array}{l}\text { "(...) Special that I said before that the city can integrate us } \\
\text { with the various areas of the City Hall, when we, when we } \\
\text { need it." (ENTSERT1) }\end{array}$ & Integrator & $\begin{array}{l}\text { Fortaleza } \\
\text { City hall }\end{array}$ & Serttel \\
\hline $\begin{array}{l}\text { "Aneel makes public calls for research projects in the area, in } \\
\text { this case, it was electric vehicles, electric mobility vehicles. } \\
\text { She wants to foster that, studies in this line." (ENTUNIF1) }\end{array}$ & Developer & Aneel & $\begin{array}{l}\text { University of } \\
\text { Fortaleza }\end{array}$ \\
\hline $\begin{array}{l}\text { "In so, my role is exactly is ahead of this project here at City } \\
\text { Hall always dealing with the actors involved, project, Serttel } \\
\text { which is Operator (...) "(ENTPREF1) }\end{array}$ & Operator & Serttelt & $\begin{array}{l}\text { Fortaleza City } \\
\text { Hall }\end{array}$ \\
\hline $\begin{array}{l}\text { "(...) the Hapvida group that is the sponsor of the project." } \\
\text { (ENTPREF1) }\end{array}$ & Sponsor & Hapvida & $\begin{array}{l}\text { Fortaleza City } \\
\quad \text { Hall }\end{array}$ \\
\hline $\begin{array}{l}\text { "There's an operator, who is Serttel, and has a sponsor that is } \\
\text { Unimed." (ENTPREF2) }\end{array}$ & Sponsor & Unimed & $\begin{array}{l}\text { Fortaleza City } \\
\text { Hall }\end{array}$ \\
\hline $\begin{array}{l}\text { "So, we have contracts today with Unifor (...) for the } \\
\text { development of research and development projects in the } \\
\text { scope of each object, of each project." (ENTENEL1) }\end{array}$ & Researcher & $\begin{array}{l}\text { University of } \\
\text { Fortaleza }\end{array}$ & Enel \\
\hline $\begin{array}{l}\text { "For VAMO Fortaleza, we had a lot of contact [with Enel], } \\
\text { because they made the electrical infrastructure possible, at } \\
\text { many points that didn't have enough power to load the cars, } \\
\text { which has this biphase, three-phase structure." (ENTSERT1) }\end{array}$ & Supporter & Enel & Serttelt \\
\hline $\begin{array}{l}\text { "We have an Association of Urban Cyclists of Fortaleza } \\
\text { that is "Ciclovida", an informal association created by civil } \\
\text { society." (ENTPREF2) }\end{array}$ & User (NGO) & Ciclovida & $\begin{array}{l}\text { Fortaleza City } \\
\text { Hall }\end{array}$ \\
\hline
\end{tabular}

Source: Research Data (2018). 
BBR

17

716

In this sample, we can see quotations identifying the main roles of the actors, a process carried out with all ST-actors, that is, during the analyzes, the records of the different actors were combined to identify the roles of each in the implementation of the initiatives. It is noted, during the analysis, the presence of multiple records, excerpts from the transcribed speeches, from different origins, identified through the codenames already mentioned. During the analysis, we focused on identifying legitimacy from different ST-actors within the results from the composition of a premise in which, for each agent identified in the structure, there are at least two indications from different sources for validation. In other words, each ST-actor is recognized by himself and at least one second ST-actor.

With this analysis, it was possible to identify the role of protagonist ST-actors in the structure of mobility initiatives. Eight key ST-actors were mapped, mainly considering their actions in the analyzed initiatives. ST-actors with peripheral performance do not participate in this group, to the point of being disregarded without prejudice to the study. Thus, for this study, the network of interactions that promotes the structuring of shared urban mobility in Fortaleza is composed of: Fortaleza City Hall, Serttel, Hapvida, Unimed - private cooperative, University of Fortaleza (Unifor) - teaching and research institution, Enel - concessionaire of electricity, Ciclovida - NGO representing users and Aneel - National Electric Energy Agency. Such ST-actors interact through public-private partnerships in the quest to institutionalize shared and sustainable urban mobility in the city (Figure 2).

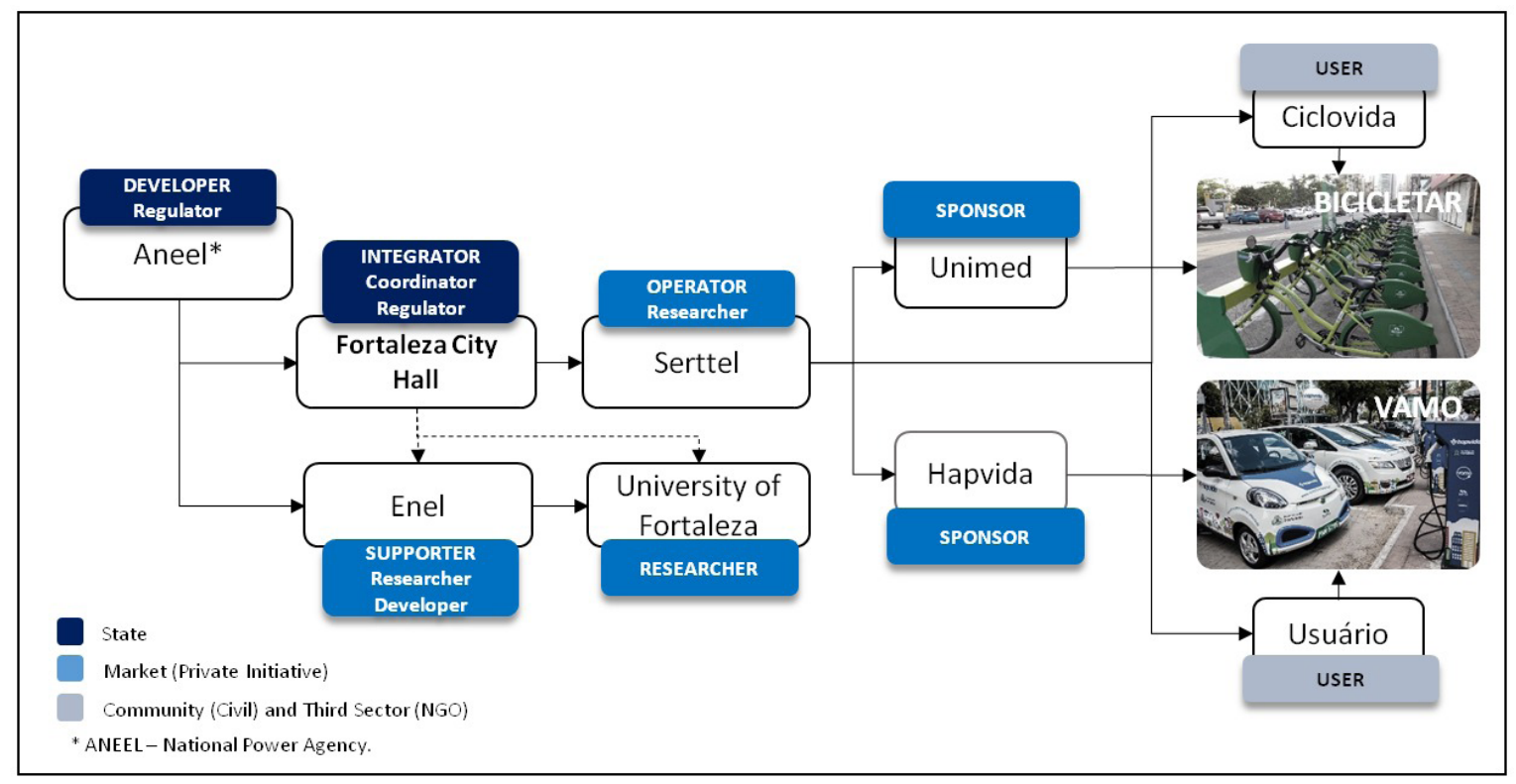

Figure 2. Representation of ST-actors and their roles.

Source: Research Data (2018).

Figure 2 illustrates the integration structure of the ST-actors, in which a grouping was carried out, distinguishing them in the categories Government, Private Initiative, and Civil Society (Wittmayer, Avelino, van Steenbergen, \& Loorbach, 2017). This grouping is seen as a way to better visualize the presence of its own triangulation and pertinent to a model of the publicprivate structure. As noted in the operator's speech, "it is very clear that we operate and do maintenance, we have our contractual duties, and on the city side, they have this management 
and control role, to supervise." (ENTSERT1). With this notion, it is understood that the PPP dynamics needs to clearly define what the roles of each ST-actor are.

In both Bicicletar and VAMO initiatives, the clear definition of roles occurs through specific contracts, including by users when accepting the terms and conditions, as well as the privacy policy. The definition of rights and duties corroborates with the stabilization of the system, generating greater transparency. In fact, the City mentions that “(...) we have individual contracts for each system, (...) Bicicletar also, (...) and VAMO also has another contract. So, each one has his contract, but the management is done within the same team, within the secretariat" (ENTPREF2).

It is valid to point out two issues in the performance of the public initiative. First, the government participates in two integrated and complementary instances: the municipal through the City Hall of Fortaleza and the federal, with the performance of Aneel. It is understood that "the electricity sector, to regulate funding for research and development, has a federal law, law 9,991 of 2,000, which determines a minimum investment of resources that comes in the energy bill for the development of innovation, for the development research, and development projects, and Aneel has a resolution that regulates the application of this resource." (ENTENEL1). Second, the relevance of the roles of the public initiative stands out since, in addition to being an integrator, coordinator and regulator, the government acts as a promoter and enables the continuous evolution of the environment, since it acts not only in the structuring of systems but also in the promotion, when legislating in favor of investments in research and innovation.

Moreover, the integrated structure of multiple ST-actors based on SE occurs through direct and indirect connections. About indirect connections, for example, the City Hall does not maintain direct contact with Hapvida, an agent that acts as a sponsor. This integration takes place indirectly, through Serttel, an agent in the role of the operator who, in turn, maintains direct contacts and contracts with the City Hall and Hapvida. As indicated during the interview, "the city coordinates on her side and looks, checks the contracts and gives very strong support to Serttel. But, for example, who has the greatest contact with the sponsor is Serttel” (ENTSERT1).

This condition is also visible in the relationship between Aneel (developer and regulator) and Unifor (researcher), whose connection between the two is intermediated by Enel, which acts mainly as a supporting agent. As noted during the interview with Enel, "today, we have contracts with Unifor and Serttel for the development of research and development projects within the scope of each object, of each project: Serttel with software, and Unifor with studies and development of market research." (ENTENEL1). This perspective highlights the existence of a clear definition of actions and roles that need to be developed for the success of the initiatives.

Therefore, amidst the composition of the structure of urban mobility in Fortaleza, the economic actors of public or private initiatives are identified, as well as the roles that each one plays. Due to the integrated visualization of these ST-actors, there is a broad understanding of the structure for the implementation of shared mobility, making it possible to view, even, different instances of action and varied types of connections between those involved. This fact is evident in the following excerpt: "When we submit to Enel, [and] when we submit to the City Hall, the results of the project stages, there is always a bias, a political, non-political view of normal politics, but political in the sense of polis, and of social benefit. A political view, of public policy that has to be considered." (ENTUNIF1).

There is the institutionalization of some practices whose purpose is focused on the integration of a new model of urban mobility, amid a pre-existing structure, in the light of the CE. It is worth mentioning, for example, the composition of an implementation plan with a focus on coexistence and not a competition, the daily alignment of the interests of ST-actors and the 
BBR

17

718

gradual understanding and adequacy of projects, based on the profile of use of citizens. The proposed structure envisions an evolutionary reconfiguration movement, which seeks to insert an innovation integrated into the current system. As indicated by the city, "so that we can also guarantee integration with the other systems in Fortaleza, VAMO, it has facilities related to the single ticket, as well as Bicicletar" (ENTPREF1). There are several nuances presented throughout this implementation, which demonstrates that the sharing economy is a path to sustainability (Heinrichs, 2013). Since there are many ST-actors involved in this process, it is understood that this process has much more complexity than initially expected.

\section{DISCUSSION}

Discussions about SE regarding sustainability are relatively recent, especially when looking for answers linked to the composition of new structures and business modalities that integrate multiple public and private ST-actors. Such discussions seek answers to the challenges currently foreseen and improve the presentation of SE as an instrument that contributes to the dimensions of sustainability. In this context, it is opportune to contribute to the analysis of how new business structures are institutionalized on different fronts, with emphasis on urban mobility.

The debate on the mobility environment gains notoriety when it concerns itself with one of the most polluting environments of the air, mainly due to CO2 emissions. Since this harmful effect is directly associated with the number and concentration of vehicles powered by combustion, it is soon seen why the most affected sites are concentrated in urban areas. In addition, studies indicate that, contrary to what seeks to contribute to the dimensions of sustainability, transport refers to one of the environments that have not yet achieved its objectives (Moradi \& Vagnoni, 2018).

For this reason, it is seen as opportune to promote business models, within the scope of urban mobility, that are generators of low $\mathrm{CO} 2$ emissions, with sharing being an alternative to be considered. Here, issues pertaining to the public and private fields were analyzed, where a better perception of the performance of economic actors involved in urban mobility was sought, not only restricted to conventional public policies but also in the composition of a network capable of configuring, with the participation of private initiative, urban mobility based on SE. In this context, shared mobility is perceived as a sustainable and economically viable business.

The technological replacement of traditional mobility systems with others with low carbon emissions and based on the premises of the SE follows a path of reconfiguration. It is possible to observe the appearance of significant changes in lifestyle based on new transport models and, for this reason, vehicle and bicycle sharing initiatives are gaining ground. In this study, the idea is reinforced in which urban reconfigurations can supplant the strength of the structures already established, but, for this, changes are required in the culture and institutional priorities that drive transport planning (Köhler, Turnheim, \& Hodson, 2018; Smith, Sochor, \& Karlsson, 2018).

Motivated by the presence of different ST-actors, it is necessary to establish a structure with appropriate governance for urban environments. For this reason, studies indicate that the challenges of urban reconfigurations must work with models with their own characteristics (Hodson \& Marvin, 2010). Despite this demand, there is no proposal for a universal model of integration, structure, and governance for the urban environment, thus creating conceptual gaps (Hodson, Geels, \& McMeekin, 2017). In this sense, the integration of public and private initiatives appears as a path in this direction (Dowling \& Kent, 2015), as observed in this research. However, this integration faces obstacles and barriers, encouraging studies on how to overcome them in the light of the concept of "mobility as a service" Mobility as a Service (MaaS) (Smith et al., 2018). 
Based on the concept of sharing mobility, opportunities emerge in different business modalities. Thus, a study carried out in the Netherlands found that the use of carsharing reduces CO2 emissions and contributed to the reduction of transport costs and the demand for parking (Nijland \& Meerkerk, 2017). Therefore, it collaborates with the composition of potential new business models, through the analysis of how public and private ST-actors can be structured for this urban reconfiguration. An integrative structure is presented and involves the expansion of studies on innovations and new business models in the light of sharing (Van Waes et al., 2018). The representation presented in this research can serve as a reference for the implementation of other projects, as well as being a reference for the construction of new paths that focus on sustainability, and seeking the insertion of more sharing business models.

\section{CONCLUSION}

Based on the arguments presented, we conclude that the integration of public-private initiatives contributes to create the stabilization of a new mobility model through the institutionalization of an integrated structure of ST-actors on both fronts, using the SE and its assumptions as a basis. This institutionalization movement appears and materializes, initially, by the composition of the identified structure, in which the integration of public and private initiatives represented here by the eight mapped organizations/actors, is presented as a basic element. It is a structure that promotes the potentization of the interests of the economic agents involved, with an emphasis on social benefit and support to the dimensions of sustainability, through SE.

Additionally, we conclude that SE in the context of urban mobility emerges as an element capable of meeting different interests and strategies of multiple ST-actors, centered on the concept of sustainability. Following an arrangement of multiple social integrations, the structure reflects the evolutionary process of relations between public and private ST-actors. Therefore, the institutionalization of roles reflects the active action of economic actors belonging to the shared urban mobility environment, under the guidance of SE and sustainability themes. In addition to the theoretical contributions presented throughout the analyzes and discussions, it is understood that this research presents a managerial contribution for private and public managers who seek to develop similar initiatives, whether in the context of mobility or in other areas focused on sustainability.

Thus, this paper has managerial implications, since the proposal presented is liable to be replicated as described, as well as in other public mobility modes based on sharing, such as electric scooters. Such replication based on a different way of integrating public and private initiatives becomes valid in promoting social (community) and business (private companies) interests. We see a unique alternative for economically viable, environmentally sustainable and socially inclusive integration, with a relevant impact on urban regimes promoted in developing and/or emerging countries.

Still, regarding management benefits, we highlight that the nature of this study reaches different frontiers. In the governmental sphere, there are gains in the potential implementation of new public policies at different levels and in multiple forms (fostering research and sustainable innovations, use of public space, new municipal mobility laws, etc.). In the civil agenda, it invites society to compose new demands, and fight for interests associated with a demonstrably inclusive mobility model. Finally, amid the private environment, it suggests the establishment of new profitable and sustainable business models. 
BBR

17

720

There are few limitations on this study, including the impossibility of gathering data from Unimed Fortaleza and Aneel directly as well as carrying out the research in a discreet (nonlongitudinal) way. However, such limitations do not detract from the expected contributions, due to the quality of the documents and other views raised. We suggest as a research agenda the continuity of investigations of the phenomena foreseen in this study in order to expand the contributions through a longitudinal analysis. Also, it is seen as contributory the inclusion of new perspectives in-depth, such as the multiple users of the urban mobility regime directly and indirectly impacted. Finally, the amplitude is gained when comparing similar actions (based on sharing) in different socio-technical conditions, for example, in other developing or emerging countries, as well as in developed countries. Such a possibility would establish new comparative frameworks and a greater universalization of contributions on the themes of PPP and sharing economy. With this vision, new research can analyze different domains in order to understand the transition to sustainability as a possible way to change practices and achieve the sustainable development goals.

\section{REFERENCES}

Akyelken, N., Banister, D., \& Givoni, M. (2018). The sustainability of shared mobility in London: The dilemma for governance. Sustainability (Switzerland), 10(2), 1-13. https://doi.org/10.3390/ su 10020420

Albuquerque, F., Bellini, C., Pereira, R., \& Mota, F. (2010). Motivaçôes para o ciberativismo anticonsumo em comunidades virtuais antimarca. Revista de Gestão dos Países de Lingua Portuguesa, 9(1-2), 64-74.

Allen, D., \& Berg, C. (2014). The sharing economy: How over-regulation could destroy an economic revolution. Fast Company, 5(11), 24-28. https://doi.org/10.1177/1536504214567860.WINTER

Appolinário, F. (2009). Dicionário de Metodologia Cientifica: um guia para a produção do conhecimento científico. São Paulo, SP: Atlas.

Bardin, L. (2016). Análise de Conteúdo. São Paulo, SP: Edições 70.

Belk, R. (2007). Why Not Share Rather than Own? Annals of the American Academy of Political and Social Science, 611, 126-140. https://doi.org/10.2307/25097913

Belk, R. (2014a). Sharing versus pseudo-sharing in web 2.0. Anthropologist, 18(1), 7-23. https://doi. org/10.13140/RG.2.1.1630.3842

Belk, R. (2014b). You are what you can access: sharing and collaborative consumption online. Journal of Business Research, 67(8), 1595-1600. https://doi.org/10.1016/j.jbusres.2013.10.001

Botsman, R., \& Rogers, R. (2010). What's mine is yours: the rise of collaborative consumption. New York: Haper Collins books.

Burnett, L. (2014). The Sharing Economy: Where We Go From Here. Leo Burnett Inc.

Canitez, F. (2019). A socio-technical transition framework for introducing cycling in developing megacities: The case of Istanbul. Cities, 94(June), 172-185. https://doi.org/10.1016/j. cities.2019.06.006

Carfagna, L. B., Dubois, E. A., Fitzmaurice, C., Ouimette, M. Y., Schor, J. B., Willis, M., \& Laidley, T. (2014). An emerging eco-habitus: the reconfiguration of high cultural capital practices among ethical consumers. Journal of Consumer Culture, 14(2), 158-178. https://doi. org/10.1177/1469540514526227 
Cavalcante, R. B., Calixto, P., \& Macedo, M. P. K. (2014). Análise de Conteúdo: consideraçóes gerais, relações com a pergunta de pesquisa, possibilidades e limitações do método. Informação $e$ Sociedade, 24(1), 13-18.

Cockayne, D. G. (2016). Sharing and neoliberal discourse: The economic function of sharing in the digital on-demand economy. Geoforum, 77(December), 73-82. https://doi.org/10.1016/j. geoforum.2016.10.005

Daunorienė, A., Drakšaitė, A., Snieška, V., \& Valodkienė, G. (2015). Evaluating Sustainability of Sharing Economy Business Models. Procedia - Social and Behavioral Sciences, 213, 836-841. https://doi.org/10.1016/j.sbspro.2015.11.486

Demailly, D., \& Novel, A.-S. (2014). The sharing economy: make it sustainable. Iddri, 3(14), 30.

Diário do Nordeste. (2019). OMS cita Fortaleza entre as cidades com mais ações para ciclistas. Retrieved November 1, 2019, from https://diariodonordeste.verdesmares.com.br/editorias/metro/ oms-cita-fortaleza-entre-as-cidades-com-mais-acoes-para-ciclistas-1.2169082

Dowling, R., \& Kent, J. (2015). Practice and public-private partnerships in sustainable transport governance: The case of car sharing in Sydney, Australia. Transport Policy, 40, 58-64. https://doi. org/10.1016/j.tranpol.2015.02.007

Economia compartilhada transforma a mobilidade humana. (2018). Retrieved February 4, 2019, from https://diariodopoder.com.br/como-a-economia-compartilhada-vem-transformando-amobilidade-humana/

Fremstad, A. (2015). Online Platforms for Exchanging and Sharing Goods. Future Economy.

Frenken, K. (2017). Political Economies and Environmental Futures for the Sharing Economy. Innovation Studies. Utrecht.

Frenken, K., \& Schor, J. (2017). Putting the sharing economy into perspective. Environmental Innovation and Societal Transitions, 1-8. https://doi.org/10.1016/j.eist.2017.01.003

Geels, F. W. (2018). Low-carbon transition via system reconfiguration? A socio-technical whole system analysis of passenger mobility in Great Britain (1990-2016). Energy Research \& Social Science, 46, 86-112.

Glind, P. van de. (2015). The rise of the "peer-to-business-to-peer" marketplace. Retrieved March 13, 2017, from http://www.collaborativeconsumption.com/2015/06/01/the-rise-of-the-peer-tobusiness/

Godoy, A. S. (2005). Refletindo sobre Critérios de Qualidade de Pesquisa Qualitativa. Gestão.Org, 3(2), 81-89.

Heinrichs, H. (2013). Sharing economy: a potential new pathway to sustainability. GAIA-Ecological Perspectives for Science and Society, 22(4), 228-231.

Hodson, M., Geels, F. W., \& McMeekin, A. (2017). Reconfiguring Urban Sustainability Transitions, Analysing Multiplicity. Sustainability, 9(299). https://doi.org/10.3390/su9020299

Hodson, M., \& Marvin, S. (2010). Can cities shape socio-technical transitions and how would we know if they were? Research Policy, 39(4), 477-485. https://doi.org/10.1016/j.respol.2010.01.020

IBGE. (2016). Estimativa da População 2016. Retrieved August 9, 2017, from http://www.cidades. ibge.gov.br/comparamun/compara.php?lang $=\& \operatorname{coduf}=0 \& i d$ tema $=130 \& \operatorname{codv}=\mathrm{V} 01 \&$ order $=$ dado $\&$ dir $=$ desc $\&$ lista $=$ CAPITAIS $\&$ custom $=$ 
BBR

17

722

Köhler, J., Turnheim, B., \& Hodson, M. (2020). Low carbon transitions pathways in mobility: Applying the MLP in a combined case study and simulation bridging analysis of passenger transport in the Netherlands. Technological Forecasting and Social Change, 151, 119314.

Krupinsk, C. (2015). Entendendo a economia colaborativa e a economia compartilhada. Retrieved January 4, 2016, from http://consumocolaborativo.cc/entendendo-a-economia-colaborativa-e-aeconomia-compartilhada/

Luna, T. F., Uriona-Maldonado, M., Silva, M. E., \& Vaz, C. R. (2020). The influence of e-carsharing schemes on electric vehicle adoption and carbon emissions: An emerging economy study. Transportation Research Part D: Transport and Environment, 79, 102226.

Martin, C. J. (2016). The sharing economy: a pathway to sustainability or a nightmarish form of neoliberal capitalism? Ecological Economics, 121, 149-159. https://doi.org/10.1016/j. ecolecon.2015.11.027

Martin, C. J., \& Upham, P. (2016). Grassroots social innovation and the mobilisation of values in collaborative consumption: a conceptual model. Journal of Cleaner Production, 134, 204-213. https://doi.org/10.1016/j.jclepro.2015.04.062

Moradi, A., \& Vagnoni, E. (2018). A multi-level perspective analysis of urban mobility system dynamics: What are the future transition pathways? Technological Forecasting and Social Change, 126(July 2017), 231-243. https://doi.org/10.1016/j.techfore.2017.09.002

Nijland, H., \& Meerkerk, J. Van. (2017). Mobility and Environmental Impacts of Car Sharing in the Netherlands. Environmental Innovation and Societal Transitions, 23, 84-91. https://doi. org/10.1016/j.eist.2017.02.001

Olsen, M., \& Kemp, S. (2015). Sharing Economy - An in-depth look at its evolution and Trajectory Across Industires. PiperJaffray, (report). https://sharingcitiesalliance.knowledgeowl.com/help/ sharing-economy-an-in-depth-look-at-its-evolution-and-trajectory-across-industries

Owyang, J. (2016). The Three Market Drivers : Causes for the Collaborative Economy. Retrieved September 29, 2016, from http://www.web-strategist.com/blog/2013/05/09/the-three-marketdrivers-causes-for-the-collabotarive-economy

Pereira, C. H. T., \& Silva, M. E. da. (2018). A Economia Compartilhada como um movimento de Transição para uma Mobilidade Sustentável. Revista de Gestão Ambiental e Sustentabilidade, 7, (3), 451-468. https://doi.org/10.5585/geas.v7i3.855

Pereira, C. H. T., \& Silva, M. E. (2017). Contribuições do Marketing na Integração Economia Compartilhada e Estratégia. Future Studies Research Journal: Trends and Strategies, 9(3), 127-149. https://doi.org/10.24023/futurejournal/2175-5825/2017.v9i3.304

Prahalad, C. K., \& Hart, S. L. (2000). Raising the Bottom of the Pyramid: Strategies for Sustainable Growth. Business, 1001, 48109. https://doi.org/10.1162/152417302760127192

Prefeitura de Fortaleza. (2017). VAMO Fortaleza. Retrieved September 16, 2017, from http://www. vamofortaleza.com/

Prefeitura de Fortaleza. (2018). Sítio Sistema Bicicletar e Mini Bicicletar. Retrieved September 8, 2018, from http://www.bicicletar.com.br/home.aspx

Rechene, S. T., Silva, M. E., \& Campos, S. A. P. (2018). Sharing Economy and Sustainability Logic : Analyzing the Use of Shared Bikes. BAR - Brazilian Administration Review, 15(3), 1-18. https:// doi.org/10.1590/1807-7692bar2018180026

Rifkin, Kj. (2016). Sociedade com custo marginal zero. São Paulo, SP: M. Books do Brasil Editora ltda. 
Rubicon. (2015). How Green is the Sharing Economy? Retrieved September 29, 2016, from http:// knowledge.wharton.upenn.edu/article/how-green-is-the-sharing-economy/

Rustrum, C., Stempinski, G., \& Liss, A. (2014). It's a shareable: a practical guide on sharing life.

Schor, J. (2014). Debating the Sharing Economy. A Great Transition Initiative Essay.

Schor, J., \& Fitzmaurice, C. (2015). Collaborating and connecting: the emergence of the sharing economy. Handbook of Research on Sustainable Consumption, (February 2014), 410-425. https:// doi.org/10.4337/9781783471270

Shaheen, S., \& Chan, N. (2016). Mobility and the Sharing Economy: Potential to Overcome Firstand Last-Mile Public Transit Connections. UC Berkeley: Transportation Sustainability Research Center. https://doi.org/10.7922/G2862DN3

Smith, G., Sochor, J., \& Karlsson, I. C. M. A. (2018). Public-private innovation: barriers in the case of mobility as a service in West Sweden. Public Management Review, 21(1), 1-22. https://doi.or $\mathrm{g} / 10.1080 / 14719037.2018 .1462399$

Soares, R. (2018). O exemplo de Fortaleza - a revolução da Ciclomobilidade. Retrieved January 20, 2019, from http://especiais.jconline.ne10.uol.com.br/exemplodefortaleza/

Sundararajan, A. (2016). The Sharing Economy: The end of employment and the rise of crowd-based capitalism. Cambridge, MA: The MIT Press.

Terama, E., Peltomaa, J., Rolim, C., \& Baptista, P. (2018). The contribution of car sharing to the sustainable mobility transition. Transfers, $8(2), 113-121$.

Terrien, C., Maniak, R., Chen, B., \& Shaheen, S. (2016). Good practices for advancing urban mobility innovation: A case study of one-way carsharing. Research in Transportation Business and Management, 20, 20-32. https://doi.org/10.1016/j.rtbm.2016.08.001

Terriena, C., Maniak, R., Shaheen, S., \& Chenb, B. (2016). Good practices for advancing urban mobility innovation: A case study of one-way carsharing. Research in Transportation Business \& Management, 20, 20-32.

Vagnoni, E., \& Moradi, A. (2018). Local government's contribution to low carbon mobility transitions. Journal of Cleaner Production, 176, 486-502. https://doi.org/10.1016/j.jclepro.2017.11.245

Van Waes, A., Farla, J., Frenken, K., de Jong, J. P. J., Raven, R., Jong, J. P. J. de, \& Raven, R. (2018). Business model innovation and socio-technical transitions. A new prospective framework with an application to bike sharing. Journal of Cleaner Production, 195, 1300-1312. https://doi. org/10.1016/j.jclepro.2018.05.223

Willing, C., Brandt, T., \& Neumann, D. (2016). Sharing is Caring - Understanding the Relationship Between the Sharing Economy and Sustainable Mobility. Icis, 1-9.

Wittmayer, J. M., Avelino, F., van Steenbergen, F., \& Loorbach, D. (2017). Actor roles in transition: Insights from sociological perspectives. Environmental Innovation and Societal Transitions, 24, 45-56. https://doi.org/10.1016/j.eist.2016.10.003

World Economic Forum. (2013). Young Global Leaders - Circular Economy Innovation \&amp; New Business Models Dialogue, 20.

World Health Organization. (2019). The power of cities: tackling noncommunicable diseases and road safety. Geneva. 
BBR

17

724
Wu, X., \& Zhi, Q. (2016). Impact of Shared Economy on Urban Sustainability: From the Perspective of Social, Economic, and Environmental Sustainability. Energy Procedia, 104, 191-196. https:// doi.org/10.1016/j.egypro.2016.12.033

Yin, R. K. (2005). Estudo de Caso. Planejamento e Métodos (3a. ed.). Porto Alegre: Bookman. 